\title{
FORMAT PENGELOLAAN DANA TABUNGAN HAJI UNTUK PEMBANGUNAN SEKTOR RIIL MELALUI SKEMA PROJECT BASED SUKUK (PBS) DALAM KAJIAN FIKIH
}

\author{
Huril 'Aini \\ Universitas Islam Indonesia Yogyakarta \\ e-mail: hurilaini959@gmail.com
}

\begin{abstract}
One form of sharia financial instrument that has been widely issued by both corporations and the state is sukuk, sharia bonds. Sukuk emphasizes investment income not on the interest rate, but on the level of income based on the level of profit sharing ratio the amount agreed upon by both parties (issuers and investors) at the time of the contract. The purpose of this research is to examine the implementation of the Project Based Sukuk (PBS) scheme of the hajj funding to fund the development of the real sector, especially infrastructure in Indonesia in the perspective of fiqh studies. In this study, the author conducts an analysis of the study of literature and scientific journals so as to produce a conclusion related to the application of PBS on hajj funding. This type of research is qualitative research. To obtain relevant data, data collection techniques such as rule review and literature study are used. The results show that the financing of infrastructure projects using PBS schemes sourced from hajj funds can be done with the following conditions: (1) sukuk issued in accordance with and fulfilling Islamic sharia rules and regulations (2) infrastructure benefits are primarily aimed at the welfare of prospective pilgrims and the general public (3) financing must be aimed at investment portfolios with low risk and provide guaranteed returns to maintain the security, usefulness and prudence of managing pilgrims funds (4) the majority of ulama agrees that the management of hajj savings funds may be invested in the project based sukuk.
\end{abstract}

Keywords: project based sukuk, sharia bonds, hajj funding

\section{Pendahuluan}

Salah satu instrumen pasar modal yang berkembang sangat pesat adalah sukuk, meskipun istilah sukuk sendiri bukan sesuatu yang baru dalam sejarah perkembangan ekonomi syariah. Istilah sukuk sesungguhnya telah dikenal sejak abad pertengahan, di mana umat Islam menggunakan istilah sukuk dalam konteks perdagangan internasional. Sukuk merupakan bentuk jamak dari kata "sakk". Sukuk dipergunakan oleh para pedagang pada masa itu sebagai dokumen yang menunjukkan kewajiban finansial yang timbul dari usaha perdagangan dan aktivitas komersial lainnya. Namun demikian, sejumlah penulis Barat yang memiliki perhatian terhadap sejarah Islam dan bangsa Arab, menyatakan bahwa term "sakk" inilah yang menjadi akar kata "cheque" dalam bahasa latin, yang saat ini telah menjadi sesuatu yang lazim dipergunakan dalam transaksi dunia perbankan kontemporer. ${ }^{1}$

\footnotetext{
${ }^{1}$ I. S. Beik, "Optimalisasi SBSN dalam Pembangunan Ekonomi Nasional”, Seminar Sukuk Negara Goes to Campus, Bogor 29 April 2011, 10.
} 
Perkembangan persaingan ekonomi global menuntut pemerintah Indonesia untuk terus meningkatkan kinerja keuangannya. Berdasarkan data Bank Dunia pada tahun 2017, Indonesia berada di peringkat 16 kekuatan ekonomi terbesar dunia berdasarkan Gross Domestic Product atau Produk Domestik Bruto (PDB) dengan nilai US\$ 1,02 Triliun. Jumlah belanja pemerintah dalam APBN 2018 sebesar 2.220,7 triliun rupiah juga mencerminkan skala ekonomi Indonesia yang besar dan memiliki potensi untuk menjadikan Indonesia sebagai negara yang kuat secara finansial sehingga memenuhi tujuan negara dalam UUD 1945, yakni memajukan kesejahteraan umum.

Dengan menggunakan model Cobb-Douglas pada data perekonomian di 26 provinsi, Prasetyo dan Firdaus menyimpulkan bahwa infrastruktur baik listrik, jalan, maupun air bersih mempunyai pengaruh yang positif terhadap perekonomian di Indonesia. Namun, instrumen keuangan yang tersedia di Indonesia untuk investasi infrastruktur tingkat lokal masih terbatas. ${ }^{2}$ Keterbatasan pendanaan menjadikan ketersediaan infrastruktur masih pada level rendah, di mana Indonesia menempati urutan ke-62 dari 140 negara dalam hal pembangunan infrastruktur peringkat yang bertahan di standar rata-rata. Keterbatasan ketersediaan infrastruktur di Indonesia tersebut dianggap sebagai hambatan utama untuk memanfaatkan peluang yang ada dalam peningkatan investasi serta menyebabkan mahalnya biaya logistik. Hal ini tentunya membuat pertumbuhan ekonomi Indonesia bergerak terbatas. Oleh karena itu, Pemerintah Indonesia telah mengagendakan percepatan pembangunan infrastruktur sebagai arah kebijakan umum pembangunan nasional dalam Rencana Pembangunan Jangka Menengah Nasional Tahun 2015-2019 (RPJMN 2015-2019). Pembangunan infrastruktur mencakup jalan, rel kereta, transportasi umum, irigasi dan saluran air, energi, dan sebagainya.

Berdasarkan data APBN selama 2004-2016, untuk utang luar negeri Indonesia saja cenderung meningkat dan telah menembus level psikologis aman selama 2014-2016. Meningkatnya utang ini sejalan dengan kebutuhan pembiayaan untuk pembangunan infrastruktur dan kegiatan produktif pemerintah lain. Walaupun belum mencapai ambang batas yang diamanatkan Undang-Undang Keuangan Negara, namun kondisi ini mau tidak mau menjadi initial warning dalam pengelolaan keuangan pemerintah yang sehat.

Menyimak APBN tahun 2017, dapat diperoleh informasi bahwa pemerintah terus melakukan peningkatan belanja yang bersifat produktif seperti pembangunan infrastruktur dan konektivitas antar wilayah, pembangunan sarana dan prasarana ketenagalistrikan, perumahan, sanitasi dan air bersih. Hal ini terlihat dari porsi pembiayaan infrastruktur yang terus mengalami peningkatan baik dari sisi jumlah maupun persentasenya terhadap total belanja negara dari tahun ke tahun.

Berdasarkan gambaran kondisi anggaran dan pembiayaan sektor riil Indonesia saat ini, termasuk infrastruktur, skema project based sukuk (PBS) dana haji, untuk setidaknya meminimalisir tren utang luar negeri Indonesia, menjadi suatu kemungkinan pendanaan yang menjanjikan. Dana haji beserta keuntungan atas investasinya sejatinya harus dimanfaatkan untuk kepentingan calon jamaah haji di Indonesia, namun manfaatnya tidak terbatas pada hal tersebut. Bentuk pemanfaatannya selama ini sekadar menutupi defisit Biaya Penyelenggaraan Ibadah Haji (BPIH) yang disetorkan jamaah dengan pengeluaran dalam pelaksanaan haji akibat perbedaan selisih kurs maupun fluktuasi harga. Jika dana haji di masa lalu hanya

\footnotetext{
${ }^{2}$ https://www.worldbank.org/en/country/indonesia.
} 
mengendap dan menjadi sumber likuiditas bagi perbankan atau hanya menjadi solusi defisit anggaran negara, maka dengan menjadikan dana tersebut sebagai sukuk untuk proyek akan lebih menggerakkan perekonomian nasional tanpa money creation. ${ }^{3}$

\section{Metode Penelitian}

Karena penelitian ini bersifat ilmiah, metode yang digunakan pun bersifat ilmiah juga. Metode ilmiah merupakan prosedur dalam mendapatkan pengetahuan yang disebut ilmu. Jadi, ilmu merupakan pengetahuan yang didapatkan lewat metode ilmiah. Tidak semua pengetahuan dapat disebut ilmu karena ilmu merupakan pengetahuan yang cara mendapatkannya harus memenuhi syarat-syarat tertentu. Syarat-syarat yang harus dipenuhi agar suatu pengetahuan dapat disebut ilmu tercantum dalam apa yang dinamakan dengan metode ilmiah. Menurut Senn, metode merupakan suatu proses atau cara mengetahui sesuatu, yang mempunyai langkah-langkah yang sistematis. ${ }^{4}$

Jenis penelitian yang digunakan dalam penelitian ini adalah penilitian kepustakaan (library research), yaitu menelaah dan mengkaji dari sumber buku-buku, jurnal ilmiah, artikel-artikel dan bentuk-bentuk bahan lain atau lazim yang berhubungan dengan penelitian. Penelitian ini bersifat kualitatif, yang digunakan untuk melihat bagaimana peran sukuk dalam pembangunan sektor riil melalui skema Project Based Sukuk (PBS).

Sumber data yang digunakan dalam penelitian ini adalah sumber data primer dan sumber data sekunder. Sumber data primer, yaitu buku atau karya-karya yang secara langsung berkaitan dengan objek material penelitian. Sedangkan sumber data sekunder yaitu sumber data yang berupa buku-buku atau kepustakaan yang berkaitan dengan objek material penelitian tetapi tidak secara langsung karya tokoh. Kepusatakaan ini lazimnya berupa kajian, komentar, atau pembahasan terhadap tokoh yang menjadi objek penelitian. Sumber data yang berupa kepustakaan yang berkaitan dengan objek formal atau buku sebagai pendukung dalam mendiskripsikan objek material penelitian. ${ }^{5}$

Sedangkan untuk analisis data menggunakan metode analisis isi (content analysis). Menurut Berelson dan Kerlinger, ${ }^{6}$ analisis isi merupakan suatu metode untuk mempelajari dan menganalisis komunikasi secara sistematik, objektif, dan kuantitatif terhadap pesan yang tampak. Sedangkan menurut Budd, ${ }^{7}$ analisis isi adalah suatu teknik sistematis untuk menganalisis isi pesan dan mengolah pesan atau suatu alat untuk mengobservasi dan menganalisis isi perilaku komunikasi yang terbuka dari komunikator yang dipilih.

\section{Definisi dan Jenis-Jenis Sukuk}

Secara etimologi, sukuk berasal dari Bahasa Arab kata sakk (jamak) yang berarti sertifikat atau bukti kepemilikan. Sukuk merupakan istilah yang berasal dari bahasa Arab dan merupakan bentuk jamak (plural). Sakk adalah buku yang mencatat kegiatan transaksi dan

\footnotetext{
${ }^{3}$ K. Musari, "Sukuk Dana Haji Untuk Pembangunan”, Harian Kontan (2 Juni 2017), 23.

${ }^{4}$ Jujun S. Suriasumantri, Filsafat Ilmu: Sebuah Pengantar Populer, Cet-24 (Jakarta: Pustaka Sinar Harapan, 2013), 119.

5 Kaelan, Metode Penelitian Kualitatif Interdisipliner bidang Sosial, Budaya, Filsafat, Seni, Agama, dan Humaniora (Yogyakarta: Penerbit Paradigma, 2012), 156-157.

${ }^{6}$ Rachmat Kriyantono, Teknik Praktis Riset Komunikasi (Jakarta: Kencana Prenada Media Grup, 2010), 232233.

${ }^{7}$ Ibid.
} 
laporan yang terjadi. Secara terminologi, sukuk merupakan surat berharga jangka panjang berdasarkan prinsip syariah yang dikeluarkan oleh emiten kepada pemegang sukuk (obligasi syariah) yang mewajibkan emiten untuk membayar pendapatan kepada pemegang obligasi syariah berupa bagi hasil/margin/fee serta membayar kembali dana obligasi ketika jatuh tempo (Berdasarkan Fatwa DSN-MUI No.32/DSN-MUI/IX/2002). ${ }^{8}$

Berdasarkan The Accounting and Auditing Organisation for Islamic Financial Institutions (AAOIFI) No. 17 tentang Investment Sukuk (Sukuk Investasi). Sukuk merupakan sertifikat dari suatu nilai yang dipresentasikan setelah penutupan pendaftaran, bukti kepemilikan dang menggunakannya sesuai rencana. Sama halnya dengan bagian dari kepemilikan aas aset yang jelas baik barang atau jasa dari suatu produk tertentu atau modal dari suatu kegiatan investasi tertentu. ${ }^{9}$

Berdasarkan kontrak aset finansial di pasar sekunder, sukuk dibagi menjadi: ${ }^{10}$

\section{Sukuk Mudärabah}

Sukuk yang diterbitkan berdasarkan perjanjian atau akad mudärabah di mana satu pihak menyediakan modal ( $r a b b$ al-mal) dan pihak lain mempunyai keahlian (mudärib), keuntungan dari kerjasama tersebut dibagi berdasarkan prosentase bagi hasil yang telah disepakati pada awal transaksi, dan kerugian yang timbul ditanggung sepenuhnya oleh pemilik modal.

\section{Sukuk Mushärakah}

Sukuk yang diterbitkan berdasarkan perjanjian atau akad mushärakah di mana dua pihak atau lebih bekerjasama menggabungkan modal untuk membangun proyek baru, mengembangkan proyek yang sudah ada, atau membiayai kegiatan usaha. Keuntungan maupun kerugian yang timbul ditanggung bersama sesuai dengan jumlah partisipasi modal masing-masing.

\section{Sukuk Ijärah}

Sukuk yang diterbitkan berdasarkan perjanjian atau akad ijarah di mana satu pihak bertindak sendiri atau melalui wakilnya menjual atau menyewakan hak manfaat atas suatu aset kepada pihak lain berdasarkan harga dan priode yang disepakati, tanpa diikuti dengan pemindahan aset.

4. Sukuk Istișnä,

Kepemilikan utang yang semakin meningkat diperoleh dari jenis pembiayaan istișnä. Sebagai contoh, pembangunan jalan yang menghabiskan dana sebesar US\$ 110 juta harus kembali tanpa adanya prinsip differensiasi dan diskon (coupon).

5. Sukuk Murabahah

Akad jual beli barang yang mana pembeli dapat membayar harga barang yang disepakati pada jangka waktu tertentu yang telah disepakati, penjual dapat menambah margin pada harga pokok barang yang dijual tersebut.

6. Sukuk Salam

\footnotetext{
${ }^{8}$ https://tafsirq.com/fatwa/dsn-mui/obligasi-syariah. Diakses pada 20 Maret 2019.

${ }^{9}$ http://aaoifi.com/standards-under-review-4/. Diakses pada 19 April 2019.

${ }^{10}$ Muhammad Iqbal Fasa, "Sukuk: Teori dan Implementasi”, Jurnal Studi Ekonomi Islam Li Falah, Volume 1, Nomor 1 (Juni 2016), 84.
} 
Dalam bentuk ini, dana dibayarkan di muka dan komoditi menjadi utang. Dana juga dapat dalam bentuk sertifikat yang merepresentasikan utang. Sertifikat ini juga tidak dapat diperdagangkan. Dapat juga diartikan salam merupakan kontrak jual beli barang dengan cara pemesanan dan pembayaran dilakukan di awal dengan syarat-syarat tertentu.

\section{Landasan Hukum Islam tentang Sukuk}

1. Dalil al-Quran

Adapun landasan hukum yang menjadi pegangan DSN-MUI dalam menetapkan bolehnya penggunaan sukuk (obligasi syariah) adalah:

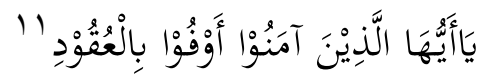

"Hai orang-orang yang beriman! Penuhilah akad-akad itu".

2. Dalil Hadis

Hadits Nabi Riwayat Imam al-Tirmidzi dari 'Amr bin 'Auf al-Muzani:

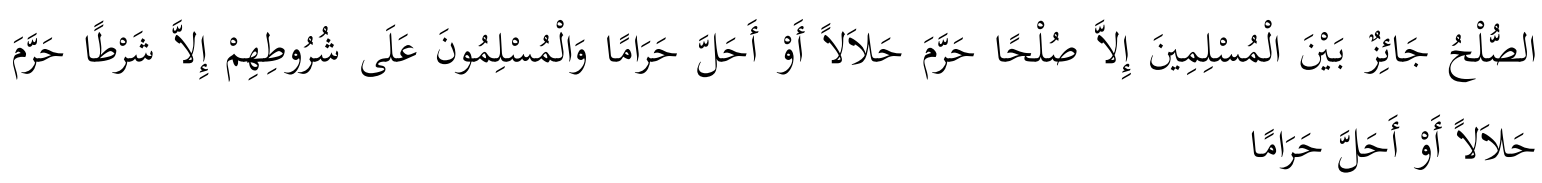

"Perjanjian boleh dilakukan di antara kaum muslimin kecuali perjanjian yang mengharamkan yang halal atau menghalalkan yang haram, dan kaum muslimin terikat dengan syarat-syarat mereka kecuali syarat yang mengharamkan yang halalatau menghalalkan yang haram".

3. Pendapat ulama fikih

Berdasarkan kaidah:

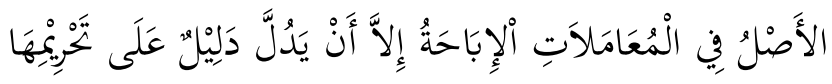

"Pada dasarnya, semua bentuk muamalah itu adalah boleh kecuali ada dalil yang mengharamkannya"

\section{Dana Haji}

Setiap warga negara yang akan menunaikan ibadah haji, wajib membayar Biaya Penyelenggaraan Ibadah Haji (BPIH). BPIH akan digunakan oleh pemerintah untuk membiayai pelaksanaan ibadah haji para calon jamaah. Namun, karena keterbatasan kuota, biasanya setiap orang yang mendaftarkan diri menjadi calon jamaah haji dan telah membayar BPIH tidak bisa langsung berangkat ke Makkah. Maka, BPIH yang terkumpul dari para calon jamaah belum akan langsung terpakai. BPIH yang terkumpul ini akan menjadi bagian dari dana haji.

Berdasarkan Undang-Undang No.34 tahun 2014 tentang Pengelolaan Keuangan Haji, dana haji adalah dana setoran biaya penyelenggaraan ibadah haji, dana efisiensi penyelenggaraan haji, dana abadi umat, serta nilai manfaat yang dikuasai oleh negara dalam rangka penyelenggaraan ibadah haji dan pelaksanaan program kegiatan untuk kemaslahatan

\footnotetext{
11 al-Quran, 5: 1.
} 
umat Islam. Badan Pengelola Keuangan Haji (BPKH) diberikan amanah untuk mengelola dana haji, termasuk melakukan investasi keuangan haji, yakni dalam bentuk surat berharga, termasuk di dalamnya SBSN atau sukuk. Implikasi dari aturan ini adalah dana haji dapat diinvestasikan dalam produk pembiayaan negara selama memenuhi syarat syar'i, dengan memperhatikan aspek:

1. Keamanan. Penempatan investasi harus memenuhi aspek prudensialitas atau keamanan investasi. Tingkat keamanan investasi ditentukan dengan melakukan analisis resiko yang matang serta berprinsip pada sikap kehati-hatian. BPKH selaku pemilik mandat pengelola keuangan haji harus memiliki kemampuan analisa finansial yang baik serta integritas yang mumpuni agar dana jamaah terlindungi.

2. Kehati-hatian. Penempatan dana haji ini harus sesuai dengan hukum syariah. Artinya, seluruh dana yang ditempatkan baik pada instrumen keuangan maupun investasi langsung harus sesuai dengan apa yang digariskan dalam al-Quran dan Hadis. Mudahnya, tidak boleh ada unsur riba dalam produk investasinya. Bentuk akad harus diawasi dan disetujui oleh lembaga yang memiliki wewenang untuk memberikan penilaian kehalalan transaksinya, misal Kementerian Agama atau Majelis Ulama Indonesia. Selain itu, pengelolaannya juga harus sesuai peraturan perundang-undangan yang berlaku.

3. Nilai manfaat. Dana haji yang diinvestasikan harus berkembang dan memiliki nilai manfaat baik bagi jamaah itu sendiri maupun kemaslahatan umat.

4. Likuiditas. Dana haji yang ditempatkan mudah untuk digunakan oleh jamaah.

5. Optimalisasi pengelolaan risiko.

Melihat persyaratan-persyaratan tersebut, serta mempertimbangkan amanah UndangUndang Pengelolaan Keuangan Haji serta potensi idle dana haji yang semakin besar dari waktu ke waktu, penempatannya untuk infrastruktur sebenarnya tidak menyalahi aturan yang ada. Namun, yang perlu diperhatikan adalah risiko dan likuiditas dari investasi yang ditanamkan. Alasannya, melalui pemanfaatan dana haji yang besar ini, seharusnya tak hanya jamaah haji yang dapat merasakan manfaatnya, tetapi berpotensi juga untuk mendorong pembangunan berkelanjutan yang pada akhirnya meningkatkan kesejahteraan masyarakat. Selain itu, yang lebih penting dari polemik penggunaan dana haji bagi infrastruktur adalah penempatan dana haji pada produk investasi.

\section{Pembiayaan Infrastruktur Melalui Sukuk Berbasis Proyek (Project Based Sukuk)}

Dalam Undang-Undang Nomor 19 tahun 2018 tentang Surat Berharga Syariah Negara, tujuan penerbitan SBSN atau sukuk negara adalah untuk pembiayaan defisit APBN dan pembiayaan proyek infrastruktur milik pemerintah. Peran sukuk negara juga telah dianggap penting sejak diterbitkannya Peraturan Pemerintah Nomor 56 tahun 2011 tentang Pembiayaan Proyek melalui Penerbitan SBSN, di mana pemerintah telah mengembangkan pembiayaan infrastruktur melalui penerbitan sukuk negara. Implementasi hal tersebut adalah dengan menerbitkan sukuk negara berbasis pembiayaan proyek atau sukuk negara dengan seri PBS (Project Based Sukuk) mulai tahun 2012.

Sukuk negara dengan seri PBS menggunakan akad ijarah (Asset to be Leased), yakni bentuk akad yang memungkinkan pemerintah menyewa aset (dalam hal ini proyek infrastruktur) yang akan diwujudkan di masa depan (sesuai masa konstruksi), namun 
pemerintah dapat membayar sewa proyek tersebut sejak dimulainya masa konstruksi. Investor sukuk (sukuk holders) akan menerima imbalan dari nilai sewa yang telah disepakati. Karena menggunakan akad ijärah, maka imbalan yang diterima oleh investor bersifat tetap (fixed return). Namun, dikarenakan proyek yang dibangun tidak menghasilkan arus penerimaan dan bersifat layanan kepada masyarakat, maka imbalan yang diberikan kepada investor sukuk negara bukan berasal dari kinerja infrastruktur tersebut. Pemerintah dapat membayar ujrah dari sumber penerimaan lainnya, misalnya pajak atau PNBP. Sukuk seri PBS terdiri dari dua jenis yaitu:

1. Project Underlying Sukuk, yang menggunakan proyek infrastruktur yang telah tercantum di dalam dokumen APBN sebagai dasar transaksinya. Sehingga, hasil penerbitan sukuk negara (proceeds) digunakan untuk mengganti dana yang telah dikeluarkan (revolving). Untuk jenis proyek yang dibiayai dengan mekanisme ini, biasanya proyek terlebih dahulu dibiayai dengan penerimaan negara yang bersumber dari pajak dan lain-lain. Setelah sukuk diterbitkan, dana hasil penerbitannnya digunakan untuk mengganti dana tersebut.

2. Project Financing Sukuk (PFS), proyek infrastruktur yang akan dibiayai melalui penerbitan sukuk negara diusulkan oleh kementerian atau lembaga melalui proses pengusulan proyek sesuai mekanisme APBN, yaitu melalui Badan Perencanaan Pembangunan Nasional (Bappenas) dan diusulkan ke Kementerian Keuangan untuk selanjutnya diusulkan dalam Undang-Undang APBN tahun bersangkutan. Proyek infrastruktur baru dapat dibiayai melalui penerbitan sukuk negara setelah proyek tersebut tercantum dalam dokumen APBN, sehingga sumber pembiayaan proyek tersebut semata-mata hanya bersumber dari sukuk negara. Penggunaan PFS dalam membiayai pembangunan sejak tahun 2013 telah mengalami peningkatan signifikan. Data menunjukkan pada tahun 2013, pagu dana dari PBS sebesar 0,3 triliun rupiah, dan pada tahun 2017 telah ditingkatkan menjadi 16,76 triliun rupiah.

Tabel 1.1. Daftar Proyek Pemerintah yang Dibiayai PFS

\begin{tabular}{|c|c|l|}
\hline Tahun & $\begin{array}{c}\text { Triliun } \\
\text { (dalam } \\
\text { Rupiah) }\end{array}$ & \multicolumn{1}{c|}{ Jenis Proyek } \\
\hline 2013 & 0,7 & Pembangunan jalur ganda rel KA \\
\hline 2014 & 1,371 & $\begin{array}{l}\bullet \\
\text { - Pembangunan jalur ganda rel KA }\end{array}$ \\
\hline 2015 & 7,135 & $\begin{array}{l}\bullet \text { Pembangunan asrama haji } \\
\text { - Pembangunan jalur } \text { elevated track KA }\end{array}$ \\
\hline 2016 & 13,677 & $\begin{array}{l}\text { - Pembangunan jualur dan balai nikah dan jalur layang rel KA } \\
\text { - Pembangunan jalan dan flyover lintas Sumatera }\end{array}$ \\
\hline 2017 & 16,67 & $\begin{array}{l}\text { - Pembangunan asrama haji dan KUA } \\
\text { - Pembangunan jalan dan sumber daya air } \\
\text { - Asrama haji dan KUA }\end{array}$ \\
\hline
\end{tabular}

Sumber: Direktorat Pembiayaan Syariah Kementerian Keuangan 


\section{Pengelolaan Dana Tabungan Haji pada PBS}

Penempatan dana haji pada sukuk negara bukan merupakan barang baru. Kementerian Keuangan bersama Kementerian Agama telah menginisiasi pengelolaan dana haji melalui Sukuk Dana Haji Indonesia (SDHI) mulai tahun 2009. Kerjasama dilakukan melalui penandatanganan kesepakatan (MoU) antara Menteri Keuangan dan Menteri Agama pada tanggal 22 April 2009. Melalui kesepakatan tersebut, dana haji dan dana abadi umat dapat ditempatkan pada portofolio Surat Berharga Syariah Negara (SBSN) dengan mekanisme penempatan pribadi, yakni penempatan langsung berdasarkan analisis dan kebutuhan dari Kementerian Agama. Sampai dengan tanggal 12 Januari 2017, outstanding SDHI masih senilai 36,7 triliun rupiah. Jadi penempatan dana haji pada sukuk negara sebenarnya membantu Kementerian Agama dalam memberikan alternatif investasi yang aman dan menguntungkan. Selain itu juga membantu dalam transparansi penempatan dana haji yang selama ini sering mendapat sorotan masyarakat.

Penempatan dana haji ke dalam SBSN sebenarnya lebih didasarkan pada keamanan dalam berinvestasi dan keuntungan. Skema SDHI memberikan keuntungan bagi Kementerian Agama dalam menentukan tenor SDHI yang disesuaikan dengan rencana pemanfaatan dana tersebut. Namun SDHI memiliki kelemahan di mana ia adalah instrumen non-tradeable (tidak dapat diperdagangkan) sehingga tidak bisa ditebus setiap saat, yang berarti kurang memenuhi aspek likuiditas yang diamanahkan Undang-Undang Nomor 34 tahun 2014. Sebenarnya Kementerian Agama dapat pula menempatkan dana haji ke sukuk negara seri PBS yang bersifat tradeable (dapat diperdagangkan) yang lebih likuid.

Polemik bermunculan di masyarakat ketika Pemerintah berencana menggunakan dana haji untuk kepentingan pembangunan infrastruktur melalui PBS. Menurut Laksono, skema penggunaan dana haji dalam sukuk yang selama ini berjalan dengan Sukuk Dana Haji Indonesia (SDHI), memiliki karakteristik yang salah satunya adalah tidak boleh menjadikan BMN (termasuk proyek berjalan) sebagai jaminan atau underlying asset, sehingga SDHI hanya boleh memiliki bentuk dan jaminan sesuai karakteristik dari sukuk itu sendiri. Bahkan, legalitas syar'i sukuk sendiri masih menjadi perdebatan para ulama dan cendikiawan muslim. Maurer dan Dusuki dalam dua penelitian yang berbeda menyimpulkan bahwa penerapan sukuk telah mendistorsi tujuan dari ekonomi Islam yang berlandaskan keadilan dan kesetaraan, di mana sukuk dipandang hanya berfokus pada aspek syar'i bentuk hukum (legal forms) dari transaksi dan substansi transaksinya sejatinya tidak berbeda dari transaksi konvensional yang mengandung riba. ${ }^{12}$

Praktek penggunaan sukuk sebagai instrumen investasi syariah telah dijamin kehalalannya oleh MUI berdasarkan Fatwa Nomor 69 tahun 2008 tentang SBSN. Penggunaan sukuk untuk pembangunan infrastruktur pun telah ditelaah dari sisi syariah. Berdasarkan keterangan Majelis Ulama Indonesia (MUI), terdapat empat syarat dana haji dapat diinvestasikan pada pengembangan infrastruktur. Pertama, dana haji boleh diinvestasikan ialah harus digunakan untuk jenis usaha yang memenuhi prinsip-prinsip

12 Muhammad Asfiroyan. "Optimalisasi Dana Haji Dalam Pembangunan Sektor Riil Melaluiskema Project Based Sukuk (Pbs)”, https://www.academia.edu/37041919/Optimalisasi_Dana_Haji_Dalam_Pembangunan_Sektor_Riil_Melalui_Ske ma_Project_Based_Sukuk_Pbs, diakses pada 12 Februari 2020. 
syariah. Kedua, terkait dengan prudensialitas atau keamanan investasi. Yakni dana haji tidak boleh berkurang setelah diinvestasikan, tapi harus berkembang dan memiliki nilai manfaat. Ketiga, investasi dana haji itu harus membawa manfaat bagi jamaah haji sendiri dan kemaslahatan bagi umat Islam. Keempat, syarat keempat terkait dengan prinsip likuiditas, dengan memperhitungkan rata-rata kebutuhan kegiatan semua jamaah haji adalah 3,5 triliun rupiah per tahun.

Pendapat MUI tersebut sesuai dengan lima aspek pengelolaan keuangan haji sesuai Undang-Undang Nomor 34 Tahun 2014, yakni keamanan, kehati-hatian, nilai manfaat, likuiditas, dan optimalisasi pengelolaan risiko. Hubungan antara calon jamaah haji dengan bank penerima setoran biaya haji bisa berdasar dua akad perjanjian. Pertama, akad wadi'ah atau berarti dana milik calon jamaah haji itu sekedar dititipkan sehingga tak ada manfaat lanjutannya atau semacam bagi hasil, dan kedua akad mudärabah atau bagi hasil.

Di beberapa negara, sukuk telah menjadi instrumen pembiayaan anggaran negara. Beberapa negara yang menjadi penerbit sukuk secara regular antara lain Malaysia, Bahrain, Brunei Darussalam, Uni Emirate Arab, Qatar, Pakistan dan Jerman. Di Malaysia, 9\% dana haji digunakan untuk investasi langsung dan $17 \%$ investasi tidak langsung pada sektor properti dan konstruksi yang memiliki imbal hasil tinggi. Pada tahun 2016, Aziz Setiawan mengatakan bahwa pemerintah perlu menerbitkan sukuk proyek untuk mendorong sektor produktif. Sebab, selama ini peran sukuk masih sebatas untuk menutupi defisit anggaran dan belum terlihat dampaknya terhadap pembangunan perekonomian nasional secara optimal. Untuk mendorong sukuk bergerak ke sektor yang lebih produktif, maka pemerintah harus mengedepankan sukuk dengan underlying project yang jelas sehingga ada dampak terhadap perekonomian. Contohnya seperti banyaknya proyek pembangunan yang ada di bawah Kementerian Perhubungan dan Kementerian Pekerjaan Umum dan Perumahan Rakyat (PUPR). Kementerian PUPR dapat bekerja sama dengan Kementerian Keuangan untuk mengidentifikasi proyek-proyek yang kemudian bisa diatur sebagai PBS. ${ }^{13}$

\section{Pengelolaan Dana Tabungan Haji pada PBS dalam Kajian Fikih}

Ada beberapa pendapat tentang apakah dana haji boleh diinvestasikan ke sukuk. Menurut Abdullah, dana haji boleh diinvestasikan dengan kriteria investasi di instrumen sesuai syariah, risiko terkendali, asas prioritas, dan persetujuan dari jamaah haji. Dalam pandangan fikih, dana haji boleh diinvestasikan karena jumlah jamaah haji yang banyak mengakibatkan daftar tunggu yang panjang. Sehingga, dana haji yang tidak terkelola dan baru bisa digunakan pada saat yang bersangkutan menunaikan ibadah haji. Investasi menjadi pilihan agar memberikan imbal hasil kepada jamaah haji dan meningkatkan kualitas penyelenggaraan ibadah haji.

Dari aspek fikih, investasi dana haji harus memenuhi ketentuan berikut. Pertama, investasi di instrumen syariah, sebagaimana ditegaskan dalam Undang-Undang Nomor 34 Tahun 2014 Pasal 2 dan Pasal 48 bahwa penempatan atau investasi keuangan haji dapat dilakukan dalam bentuk produk perbankan, surat berharga, emas, investasi langsung dan

\footnotetext{
13 Aziz Setiawan, "Penerbitan Sukuk Diprediksi Terus Meningkat", https://www.republika.co.id/berita/ekonomi/syariah-ekonomi/17/01/08/ojgsat382-penerbitan-sukuk-diprediksiterus-meningkat, diakses pada 12 Februari 2020.
} 
investasi lainnya yang dilakukan sesuai dengan prinsip syariah dengan mempertimbangkan aspek keamanan, kehatian-hatian, nilai manfaat, dan likuiditas. Menurut Islam, kriteria ini menjadi keharusan. Investasi dana haji di instrumen konvensional seperti deposito bank konvensional dan obligasi tidak diperbolehkan. Sebab, kredit berbunga yang diharamkan sebagaimana ditegaskan dalam fatwa DSN MUI dan standar syariah AAOIFI. Di antara instrumen sesuai syariah tersebut adalah deposito bank syariah dengan skema mudärabah, surat berharga syariah negara (SBSN) atau sukuk negara dengan skema asset to be leased, ijärah sale and lease back, wakalah atau wakalah bi al-istithmar, sukuk korporasi, dan sektor riil yang sesuai syariah.

Kedua, investasi tersebut memberikan imbal hasil yang tinggi dengan risiko yang bisa dikendalikan. Sebagaimana ditegaskan dalam undang-undang bahwa sebagian dana haji dapat ditempatkan atau diinvestasikan dengan prinsip syariah dan mempertimbangkan faktor risiko serta bersifat likuid (pasal 46 ayat 3). Dalam Islam, mitigasi risiko dalam investasi menjadi bagian maqāsisid al-sharīah (tujuan yang ingin dicapai dalam syariah), yaitu menjaga harta (hifdh al-mal min jāib al-wujūd) sebagaimana dijelaskan oleh Ibnu Taimiyah yang mengatakan bahwa akad musāqah dan muzära'ah diberlakukan dengan mengandalkan komitmen (amānah) pengelola, sesuau yang sulit terjadi atau sulit dilakukan. Oleh karena itu, masyarakat membutukan akad ijärah. Melalui akad ijärah, harta yang disewakan itu terjamin. Oleh karena itu, masyarakat di banyak tempat dan kondisi meninggalkan transaksi muzära'ah dan memilih ijarah sebagai alternatif karena sebab tersebut.

Ketiga, asas kemanfaatan dengan memilih instrumen yang lebih luas manfaat dan maslahatnya. Kaidah fikih prioritas mendahulukan maslahat yang lebih besar dan jangka panjang dari pada mashlahat terbatas dan jangka pendek. Keempat, investasi dilakukan atas persetujuan dan kesepakatan dengan jamaah haji secara individu sebagai pemilik dana dan diperuntukan atas seizin mereka. Seluruh imbal hasil investasi ini digunakan untuk meningkatkan kualitas penyelenggaraan ibadah haji, meningkatkan rasionalitas dan efisiensi penggunaan BPIH, serta meningkatkan manfaat bagi kemaslahatan umat Islam (Pasal 3 Undang-Undang Nomor 34 Tahun 2014).

Menurut Cholil Nafis, menggunakan hasil manfaat pengelolaan dana haji milik calon jamaah haji untuk menutup biaya jamaah haji yang sedang berangkat menunaikan ibadah haji tanpa akad yang jelas dan diketahui pemilik dana hukumnya haram. Sebab, dana manfaat itu sebagian milik jamaah calon haji yang masih menunggu, sementara seluruh manfaatnya digunakan oleh jamaah yang sedang menunaikan ibadah. Artinya, sebagian biaya penyelenggaraan ibadah haji didapat dari harta orang lain tanpa akad yang jelas.

Dinilai dari sudut pandang syariah, setiap bentuk muamalah harus disertai dengan akad yang jelas dan disepakati semua pihak di awal. Oleh karena itu, BPKH menerapkan akad wakalah untuk mengelola dana haji. Isi akad wakalah atau surat kuasa setoran awal dana haji terdiri dari identitas calon jamaah, pernyataan pemberian kuasa dari calon jamaah haji dalam pengelolaan dana, bentuk-bentuk pengelolaan dana oleh BPKH, dan pernyataan pemberian kuasa calon jamaah haji kepada BPKH untuk memproses penerimaan dan melaksanakan amanat sesuai dengan peraturan perundangan. Akad wakalah tersebut telah mendapat dukungan dari DSN-MUI. 
Di luar berbagai perbedaan pandangan di atas, kita sepakati bersama bahwa ada penumpukan dana haji dalam jumlah yang sangat masif yang merupakan dampak dari semakin meningkatnya keinginan masyarakat untuk menunaikan ibadah haji dan jadwal tunggu keberangkatan yang semakin lama karena keterbatan kuota haji. Untuk memperoleh daftar tunggu, jamaah haji harus melunasi setoran awal senilai kurang lebih 25 juta rupiah. Dapat dibayangkan dana yang terkumpul apabila saat ini calon jamaah haji yang masih berada di dalam daftar tunggu mencapai 1,96 juta orang. Pada akhir tahun 2016, diperkirakan total setoran dana haji ke Kementerian Agama mencapai 76 triliun rupiah dan tidak lama lagi akan menembus angka 100 triliun rupiah.

Untuk menjamin terwujudnya idealitis pengelolaan keuangan haji, pemerintah berlandaskan Undang-Undang Nomor 34 Tahun 2014 tentang Pengelolaan Keuangan Haji, dapat mengelola dana haji yang dikumpulkan dari calon jamaah. Sebagaimana telah dijelaskan sebelumnya, undang-undang ini menjadi dasar dibentuknya BPKH yang memiliki tugas mengelola keuangan haji, termasuk investasinya. Dalam undang-undang, BPKH diberikan batasan prinsip dan aspek yang perlu diperhatikan dalam menginvestasikan dana haji, namun tidak membatasi sektor investasi pada infrastruktur. Di sisi lain, jika dana menumpuk terlalu banyak dan tidak dikelola, itu akan menimbulkan kemubaziran. Dan Islam melarang umatnya untuk menghambur-hamburkan harta dan melarang keras tindakan mubazir. Allah SWT berfirman: dalam QS. Al-Isra' ayat 26-27:

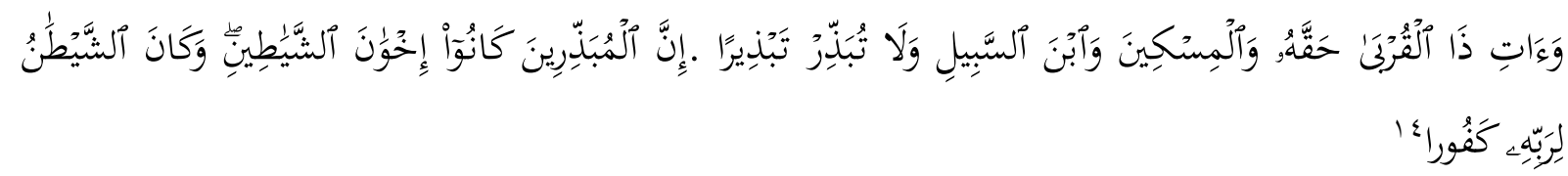

"Dan berikanlah kepada keluarga-keluarga yang dekat akan haknya, kepada orang miskin dan orang yang dalam perjalanan dan janganlah kamu menghambur-hamburkan (hartamu) secara boros. Sesungguhnya pemboros-pemboros itu adalah saudara-saudara setan dan setan itu adalah sangat ingkar kepada Tuhannya".

Saat ini, dana haji yang telah terkumpul biasanya diinvestasikan ke deposito di beberapa perbankan syariah di Indonesia dan setara kas. Penempatan dana haji pada perbankan syariah memberikan dampak positif karena perbankan syariah memperoleh dana yang jumlah besar sehingga dapat mengembangkan fungsi intermediasinya terhadap sektor riil. Namun, dana haji yang sangat besar jumlahnya tersebut tidak dapat ditempatkan semuanya ke dalam perbankan syariah karena keterbatasan perbankan syariah mengelola dana tersebut. Sehingga alternatif lain yang paling baik adalah menempatkannya pada sukuk negara, termasuk sukuk berbasis proyek.

Kemudian, apakah sukuk bisa mendorong pertumbuhan ekonomi di Indonesia? Menurut Datuk, dengan asumsi variabel-variabel lain seperti regulasi, tingkat korupsi, situasi sosial politik yang kondusif dan lain-lain mendukung, dapat dipastikan akumulasi modal yang berasal dari penjualan sukuk negara akan menimbulkan akselerasi dalam pertumbuhan

\footnotetext{
${ }^{14}$ al-Quran, 17: 26-27.
} 
ekonomi. Dengan dukungan dana sukuk tersebut pemerintah akan lebih cepat merealisasikan pembangunan infrastruktur yang akan mendorong pertumbuhan ekonomi kedepannya. ${ }^{15}$

\section{Kesimpulan}

Pertama, penempatan dana haji melalui mekanisme PBS sejatinya memiliki tujuan agar pengelolaan keuangan calon jamaah haji bisa lebih aman dan likuid dibandingkan SDHI, serta lebih sesuai dengan amanah Undang-Undang Pengelolaan Keuangan Haji. Bentuk investasi tersebut juga dinilai mampu memberikan imbal hasil lebih tinggi dibandingkan dengan investasi berbasis syariah lain seperti deposito. Dana haji juga akan memberikan economic added value yang lebih baik, karena dana tersebut berputar pada sektor riil yang dijamin pemerintah dengan proyek pembangunan. Namun, penempatan dana haji pada PBS harus memperhatikan beberapa syarat tertentu.

Kedua, dana haji memiliki potensi multiplier effects yang besar. Di satu sisi, ketika dana tersebut ditempatkan dalam sukuk PBS, maka akan membantu pembangunan infrastruktur yang mampu menggulirkan pertumbuhan ekonomi dengan banyaknya lapangan kerja baru yang dibuka dan masyarakat yang dibuat sejahtera. Di sisi lain, penempatan pada sukuk negara juga memberikan imbalan yang cukup kompetitif. Hasil imbalan ini dapat dimanfaatkan untuk meningkatkan kualitas layanan haji sehingga masyarakat Indonesia lebih nyaman dan aman dalam menjalankan ibadah haji. Apabila kebaikan-kebaikan ini disampaikan kepada masyarakat pemilik dana haji, diyakini masyarakat ikhlas terhadap penempatan dana haji yang transparan dan dapat mengundang keberkahan dari Allah SWT bagi bangsa.

\section{Daftar Rujukan}

Beik, I. S. “Optimalisasi SBSN dalam Pembangunan Ekonomi Nasional”, Seminar Sukuk Negara Goes to Campus, Bogor, 29 April, 2011.

Datuk, B. "Sukuk Dimensi Baru Pembiayaan Pemerintah Untuk Pertumbuhan Ekonomi", Jurnal Riset Akuntansi dan Bisnis, Volume 2, Nomor 1 (2014).

Fasa, Muhammad Iqbal. "Sukuk: Teori dan Implementasi”, Jurnal Studi Ekonomi Islam Li Falah, Volume 1, Nomor 1 (Juni 2016).

Kaelan. Metode Penelitian Kualitatif Interdisipliner Bidang Sosial, Budaya, Filsafat, Seni, Agama, dan Humaniora. Yogyakarta: Penerbit Paradigma, 2012.

Kriyantono, Rachmat. Teknik Praktis Riset Komunikasi. Jakarta: Kencana Prenada Media Grup, 2010.

Musari, K. “Sukuk Dana Haji Untuk Pembangunan”, Harian Kontan, 2 Juni 2017.

Peraturan Presiden Nomor 2 Tahun 2015 tentang Rencana Pembangunan Jangka Menengah Nasional Tahun 2015-2019.

Prasetyo, R. B. dan M. Firdaus. "Pengaruh Infrastruktur pada Pertumbuhan Ekonomi Wilayah di Indonesia", Jurnal Ekonomi dan Kebijakan Pembangunan, Volume 2, Nomor 2 (2009).

Suriasumantri, Jujun S. Filsafat Ilmu: Sebuah Pengantar Populer, cet. 24. Jakarta: Pustaka

15 B. Datuk, "Sukuk Dimensi Baru Pembiayaan Pemerintah Untuk Pertumbuhan Ekonomi", Jurnal Riset Akuntansi dan Bisnis, Volume 2, Nomor 1 (2014), 4. 
Sinar Harapan, 2013.

Undang-Undang Nomor 13 Tahun 2008 tentang Penyelenggaraan Ibadah Haji.

Undang-Undang Nomor 34 Tahun 2014 tentang Pengelolaan Keuangan Haji.

http://aaoifi.com/standards-under-review-4/

https://academia.edu/37041919/Optimalisasi_Dana_Haji_Dalam_Pembangunan_Sektor_Riil_

Melalui_Skema_Project_Based_Sukuk_Pbs

https://republika.co.id/berita/ekonomi/syariah-ekonomi/17/01/08/ojgsat382-penerbitan-sukuk-

diprediksi-terus-meningkat.

https://tafsirq.com/fatwa/dsn-mui/obligasi-syariah

https://worldbank.org/en/country/indonesia 